\title{
A Filosofia e seu ensino como phármakon
}

\section{The teaching of Philosophy as pharmakon}

\author{
Walter Omar Kohan ${ }^{1}$
}

\begin{abstract}
RESUMO
O presente texto busca problematizar o valor e o sentido de ensinar filosofia a partir de sua caracterização como phármakon a partir das figuras de Sócrates e Platão. Numa primeira parte, destaca a forma em que Sócrates apresenta a Filosofia, as suas condições e a ele próprio como filósofo no Fedro e em passagens de outros diálogos de Platão; num segundo momento, detalha a condenação de Platão à escrita no Fedro, levando em consideração aportes críticos de J. Derrida e G. Deleuze para estabelecer o que está em jogo nessa condenação; numa terceira seção, apresenta os efeitos pedagógicos e políticos dessa condenação e como ela coloca Platão numa posição surpreendentemente oposta em relação ao seu próprio mestre, Sócrates. Finalmente, são extraídas algumas conclusões dessa disputa e do valor que ela pode ter para o que hoje pensamos sobre o ensino de Filosofia no Brasil.
\end{abstract}

Palavras-chave: ensino de Filosofia; Sócrates; J. Derrida; pharmakon.

\begin{abstract}
This article goes back to Socrates and Plato to reach for elements that help us to think about the meaning and sense of teaching Philosophy through the concept of pharmakon. In the first section, we present a characterization that Socrates makes on Philosophy, its conditions and on himself as a philosopher in Phaedrus and in some other dialogues by Plato; the second section offers details of Plato's condemnation for writing in Phaedrus, taking into consideration the criticism of J. Derrida and G. Deleuze to establish what is at stake in that censure; in the third section, the peda-
\end{abstract}

\footnotetext{
${ }^{1}$ Pós-doutor em Filosofia pela Universidade de Paris 8 (2008) e professor titular de Filosofia da Educação da Universidade do Estado do Rio de Janeiro (UERJ), bolsista do Conselho Nacional de Desenvolvimento Científico e Tecnológico (CNPq) e da Fundação Carlos Chagas Filho de Amparo à Pesquisa do Estado do Rio de Janeiro (FAPERJ), Brasil. E-mail: wokohan@gmail.com
} 
gogical and political effects of such condemnation are presented, and also how it places Plato in a surprising opposite position in relation to his own teacher, Socrates. Finally, there are some conclusions of that combat and of its value for those who are now thinking the teaching of Philosophy in Brazil in the present moment.

Keywords: teaching Philosophy; Sócrates; J. Derrida; pharmakon.

Este texto é um ensaio sobre o sentido político de ensinar Filosofia no Brasil dos dias de hoje. Fá-lo em diálogo com duas figuras antigas, mas também contemporâneas da Filosofia, Sócrates e Platão, essa dupla enigmática que constitui decisivamente a tradição posterior. Estabelece para isso o seguinte percurso: numa primeira parte, destaca a forma em que é apresentada a Filosofia, e suas condições, a partir de algumas passagens de diálogos de Platão. Ênfase particular dessa primeira seção recebe um dos autorretratos que Platão escreve no nome da personagem Sócrates no Fedro. Dessa forma, o leitor pode encontrar sentidos para uma vida filosófica como a de Sócrates, na qual viver e ensinar não se dissociam facilmente, e ser filósofo ou professor de Filosofia também são formas inseparáveis de uma mesma vida. Numa segunda seção, a condenação de Platão à escrita no Fedro é apresentada com certo detalhe, acompanhada da leitura crítica de J. Derrida e G. Deleuze sobre a importância dessa condenação; numa terceira seção, os efeitos pedagógicos e políticos da disputa mostram Platão numa posição surpreendentemente oposta em relação ao seu próprio mestre, Sócrates, no que diz respeito ao papel do filósofo/professor de Filosofia na educação dos jovens. Finalmente, são apresentados os desdobramentos dessa disputa para pensar o sentido atual do ensino de Filosofia no Brasil.

\section{A apresentação do filósofo e da Filosofia}

A vida de Sócrates, e sua morte, estão marcadas por uma relação muito próxima com o phármakon, traduzido como remédio, veneno, droga, medicina. No Fédon, depois de conversar com seus amigos, Sócrates bebe o phármakon que, cumprindo a condenação, leva seu corpo à morte, mas - ele quer convencer seus amigos - também sua alma a uma nova vida. Não há razões para se entristecer, insiste: a morte é a forma de uma nova vida, mais livre, pura, profunda. No Fedro, o phármakon é um discurso em papiros que leva Sócrates até os confins da pólis para ouvir, do Fedro, o discurso que Lísias proferiu sobre o amor. Ali afirma que o phármakon é uma das únicas coisas que faz perder a Sócrates o 
controle de si mesmo, tanto que seguiria Fedro a qualquer lugar com o objetivo de ouvir o que tem para lhe dizer.

Uma maior proximidade da vida de Sócrates com o phármakon é manifesta em outros diálogos. Em uma passagem do Mênon, Mênon acusa Sócrates de tê-lo enfeitiçado e drogado (geoteúeis me kai pharmátteis, 80a). Sócrates o reconhece sem problemas, apenas coloca uma condição: que se leve todos os outros ao phármakon da aporía, porque ele está mais em aporía do que ninguém. No Cármides, Sócrates é apresentado por Crítias como conhecedor da droga (ho tò phármakon epistámenos, 155c) que poderá curar a dor de cabeça de Cármides (“cuidar da alma com algumas poções", epoidaîs tisin, 157a).

De uma forma próxima a como ele é retratado por outros e por si mesmo, Sócrates retrata Eros no Banquete (203ss.): daímon, ser intermédio que passa a vida inteira filosofando (philosophôn dià pantòs toû biou, 203d), nem mortal (ser humano), nem imortal (deus), feiticeiro terrível, bruxo e sofista (deinòs góes kai pharmakeús kai sophistés, 203d-e). Parece sem dúvidas um autorretrato: em muitas passagens dos diálogos, Sócrates recebe essas características, inclusive de Agatão no próprio Banquete (194a).

No Teeteto, Sócrates diz ter a mesma arte da sua mãe, a parteira Fenareta, e também afirma que as parteiras, por meio de drogas (pharmakía, 149c) e poções, são capazes de provocar ou aliviar dores de parto, parir ou abortar partos difíceis. As parteiras são mulheres que pariram - não poderiam ajudar a realizar algo que nunca experimentaram - mas já não podem mais parir, tornaram-se estéreis. $\mathrm{O}$ mesmo vale, diz Sócrates, para a sua arte de dar à luz: ele mesmo já é estéril, com a diferença de que faz os homens e não as mulheres dar à luz, examinando as almas, mas não os corpos que engendram conhecimentos (150b). O mais importante da arte de Sócrates é sua capacidade, potência, para ser, de qualquer forma, uma pedra de toque (basanizein dynatòn eînai pantì trópoi, 150c). Embora a forma com que Platão descreve esse trabalho sobre o pensamento do jovem seja muito próxima à do Fedro (Sócrates ponderaria se o jovem dá à luz uma imagem - ou simulacro - e uma mentira ou algo fecundo e verdadeiro, eídolon kaì pseudos... gónimon te kaì alethés, 150c), ele o faz inspirado pela familiaridade com o phármakon, vinda de sua mãe. Essa familiaridade, herdada de sua mãe parteira, é a condição que permite a Sócrates desenvolver essa capacidade.

Como Derrida o assinalara, não há unicidade no phármakon (DERRIDA, 1991, p. 41 ss.). Ao contrário, ele é contraditório; seu sentido é impossível de ser fixado num dos contrários sem a presença do outro. Enquanto substância, é a antissubstância: o veneno é sempre remédio; a droga, sempre medicina; a vida, sempre morte... Platão o confirma apresentando, no mesmo Fedro, o remédio (a dialética) como veneno (escrita, graphé). De modo que a proximidade de Sócrates com o phármakon está também afetada por esse caráter contraditório 
do phármakon, que lhe outorga tanto a possibilidade quanto a impossibilidade de ser o que é. Essa proximidade parece também contagiar o próprio Sócrates, impossível de ser fixo numa identidade sem contradições. Contudo, o phármakon exige um andar mais atento. Vamos mais devagar.

Abrimos o Fedro desde o início. O que encontramos? Sócrates e, com ele, um enigma infinito, o da Filosofia, ou melhor, o de qualquer professor de Filosofia, de todo educador filosofante: o que fazer em nome de uma vida filosófica? Como, por que e com quais sentidos convidar outros a essa vida? Com que direito? Com quais sentidos? O enigma se mostra também sob a forma de uma ausência: encontramos Sócrates e não encontramos Platão. Platão escreve, mas não se escreve. A ausência não é ocasional: como sabemos, Platão só se menciona umas poucas vezes, na Apologia, para contar-se como um dos que contribuiria a pagar uma eventual multa a favor de Sócrates, e no Fédon, para dizer que estava doente e, portanto, ausente, na despedida do mestre. Fora delas, sequer aparece mencionado nos diálogos que ele próprio escreveu. Essa ausência marcou decisivamente a Filosofia. O mestre, o primeiro a inscrever a Filosofia como exercício da palavra com outros na pólis, não escreve. Um discípulo o escreve se escondendo, por escrito, na máscara do mestre.

Essa ausência mostra também o insuportável não-lugar de todo aprendiz de Filosofia. Como se aprende a pensar? Qual relação estabelecer com o mestre? $\mathrm{O}$ que aprender dele? $\mathrm{O}$ mestre infinito fala sem escrever e o discípulo desobediente escreve essa ausência. O mestre não escreve e é escrito por um discípulo que condena a escrita e, por escrito, escreve sua Filosofia a partir da Filosofia do mestre. Repetição e diferença indecifráveis. Assim é a Filosofia, uma dupla insuportável, como J. Derrida sugere (DERRIDA, 1980, p. 56).

Abrimos o Fedro então e, já no início, encontramos esse enigma da Filosofia, um pensamento a ser elaborado e reelaborado até o infinito, um diálogo inverossímil, um mistério perene, o do próprio pensamento em diálogo consigo mesmo, impossível de elucidar, mas também de iludir. Encontramos uma virtualidade que exige ser sempre desdobrada, atualizada, estendida nas mais diversas dimensões, inesgotável, irresolúvel, louca.

Lendo o Fedro nos dispomos a iniciar mais uma dobra desse movimento, da infinita abertura do pensamento inaugurado por Sócrates e Platão, essa dupla inseparável. Repetimos o gesto de tantos. Não sabemos a intensidade de nossa marca antes de escrevê-la. No momento atual desse movimento, o phármakon da escrita está dentro da própria Filosofia.

Mais uma vez, é preciso atenuar a velocidade. Voltamos a olhar para o início do Fedro. O que encontramos? Sócrates encontra Fedro, que está vindo da casa de Lísias, o mais hábil em escrever discursos entre os atenienses. Ele leva consigo um phármakon, discursos en papiro sob o manto e, com ele, como 
um ímã, arrasta Sócrates até os confins da pólis. Fedro e Sócrates andam, caminham, estão em pé, em movimento. Já o afirmamos: a Filosofia é uma conversa infinita. Buscam, conversando, um lugar mais propício para sentir o discurso de Lísias. Sócrates está perdido. Descoberto o phármakon, faria qualquer coisa para ouvi-lo. O que encontramos no início, então, é o desejo do filósofo de escutar de alguém o que um terceiro, afamado conhecedor, manifesta saber sobre certo saber.

Lísias tem discursado diante de Fedro e outros em relação ao amor (erotikòs) de uma forma que o próprio Fedro não sabe muito bem como explicar. O tema não é pouco significativo: acerca das coisas do amor, é a única das quais Sócrates reconhece saber nos diálogos ("nada diferente afirmo saber que as coisas do amor" (oudén phemi állo epistàsthai è tà erotiká, Banquete, 177d). Também diz de quem aprendeu o que sabe do amor nesse mesmo diálogo: de uma mulher, sacerdotisa, estrangeira, Diotima de Mantinéia (Banquete, 201d). O filósofo só sabe o que sabe de uma dupla forma de exterioridade, e sabe um saber de relação, de afeto, de paixão.

De modo que o mais valioso dos escritores proferiu um discurso sobre o único saber que o filósofo admite saber, o saber que lhe é mais próprio, um saber que o leva à loucura. É aí a força do phármakon. Frente a ele, Sócrates se perde a si mesmo: não pode não querer ouvi-lo. Está tão fora de si que seria capaz de fazer qualquer coisa se Fedro não aceitasse contar-lhe o que ouviu de Lísias. Assim, começa então o filósofo: buscando, com outros, um lugar para ouvir o que outros dizem saber sobre o saber que lhe é mais próprio, sobre esse saber sem o qual ninguém que vive segundo a Filosofia poderia viver: o amor, um saber de relação, de sensação, de paixão, de encontro com outros corpos e outras almas. Assim, começa então a busca de um filósofo: com um desejo, um saber e um caminho a ser percorrido com outro sobre o que lhe é mais vital e, ao mesmo tempo, coloca sua vida em questão.

O filósofo não conversa com qualquer um. $\mathrm{O}$ interlocutor não é um desconhecido. Ao contrário, Sócrates manifesta conhecer Fedro de uma forma tão íntima que não conhecê-lo significaria também esquecer-se de si mesmo (Fedro, 228a). Não é um detalhe para quem, como Sócrates, se mostra sempre obsessivamente preocupado em conhecer-se a si mesmo. A relação entre conhecimento e esquecimento de si também aparece fortemente num momento crucial, no início da Apologia de Sócrates (17a), quando, estando sua vida em jogo e depois de ter ouvido a apresentação das acusações contra ele, Sócrates manifesta que eles foram tão convincentes que, mesmo afastados da verdade, quase conseguiram que ele se esquecera de si mesmo. $\mathrm{O}$ "quase" marca o risco de uma morte talvez mais vital para o filósofo que aquela que está sendo processada. Nos dois casos, o risco de se esquecer de si próprio aparece perante o poder da palavra proferida 
pelo outro da Filosofia, o retórico. Contudo, no início do Fedro, se conhecer a si próprio supõe conhecer o outro amigo da Filosofia com quem se conversa, ambos os conhecimentos são a condição para ouvir o discurso perigoso do outro da Filosofia. Não é apenas Sócrates quem conhece Fedro. Também Fedro conhece Sócrates, tanto que ele vai dizer palavras muito semelhantes (236c) a Sócrates logo depois de ler o discurso de Lísias, quando aquele ameaça não querer dizer o que pensa a respeito. A Filosofia é uma conversa entre amigos.

Ainda estamos no início do Fedro e não estão dadas todas as condições para começar a filosofar. Não são poucas. É preciso considerar muitas outras coisas: a temperatura externa e a do corpo, o ar que se respira, a tranquilidade do ambiente para não serem interrompidos, um som de ambiente agradável, música para os ouvidos. E, sobretudo, é necessário tempo. Há que se dispor de tempo para filosofar. Tempo livre, daquele que não pode ser medido pelos cronômetros ou pelos relógios, tempo de inícios sem fim, sem pressas, sem condições mais do que as emanadas da própria conversa. Tempo para conversar sobre o que não é urgente e produtivo, tempo compartilhado, comum, tempo de amizade, tempo de verdade. Fedro e Sócrates dispõem desse tempo e encontram também um lugar apropriado para conversar.

Uma vez estabelecidas essas condições, o filosofar começa quando Sócrates afirma um saber paradoxal sobre si. Manifesta-se incapaz de se conhecer a si próprio apenas algumas linhas depois de ter afirmado que não conhecer a Fedro significaria se esquecer de si próprio. Porém, como é possível que se esqueça do que não se conhece? Só resulta possível para alguém tão próximo do phármakon como Sócrates. Ele parece enfrentar exigências opostas: por um lado, se reconhecesse se conhecer a si mesmo, então já não poderia dedicar sua vida a se investigar a si próprio, como afirma no Fedro e em tantos outros lugares, pois para que iria investigar o que já conhece? Por outro, se não se conhecesse, também não poderia se dedicar a essa vida, pois é esse conhecimento que justifica e outorga sentido a uma vida de busca de si. De modo que Sócrates parece embaraçado: conhecer-se e desconhecer-se são ambos impossíveis e necessários. Como o phármakon, como a Filosofia na pólis, como a única vida que faz sentido de ser vivida por Sócrates, a que o leva à morte... Talvez por isso Fedro descreve Sócrates como o mais extraordinário, sem lugar e estranho (atopótatós, 230c) de todos os atenienses, alguém que, embora nunca extrapole os limites da cidade, parece mais um estrangeiro sendo guiado (xenagouménoi, 230c) do que alguém natural de Atenas. Sócrates complementa esta apresentação: reivindica-se como alguém amante de aprender, mais interessado em aprender dos homens da cidade do que das árvores e dos campos. 


\section{A condenação à escrita}

A seguir, Fedro lê apaixonadamente o discurso de Lísias. Sócrates se volta contra ele em diversos sentidos: na forma; afirma que ele é repetitivo, dizendo as mesmas coisas de uma e outra maneira, como uma criança (235a); no conteúdo, Sócrates cita poetas (Safo e Anacreonte) como possíveis fontes de inspiração para falar melhor sobre o mesmo assunto. Contudo, antes de criticar o discurso de Lísias, volta a falar sobre si: amante como é das palavras (philológoi, 236e), fala primeiro com a cabeça coberta para evitar a vergonha no olhar de Fedro. A imagem é muito forte: falar sem olhar para o amigo um discurso que não resiste às exigências de um cara a cara. Em qualquer caso, Sócrates muda a perspectiva de análise porque, para saber o que Lísias afirma saber, qual seja, se é preciso amar mais a quem não corresponde do que a quem ama, trata-se de deliberar primeiro sobre a essência do amor, sobre o que é o amor.

Segue-se um relato do qual depois o próprio Sócrates se desculpa e emenda a cara descoberta com outro muito mais poético que acaba com um exultante elogio a Éros. Assim, a Filosofia se mostra como um saber de e sobre o amor. Em seguida, Lísias é criticado, mas a questão não é apenas Lísias, senão todos os autores de discursos escritos, os logógrafos. Sócrates o diz claramente: não é vergonhoso escrever, mas sim escrever mal e sem beleza (258d). É preciso então examinar o que significa escrever bem. Antes, Sócrates contará o mito das cigarras, discutirá a relação entre retórica e verdade e analisará em detalhe o discurso de Lísias, através de outros relatos. Também falará outra vez de si: apresenta-se como amante das divisões e das reuniões, que lhe permitem falar e pensar. Chama-se indiretamente de "dialético, capaz de olhar para o uno e o múltiplo" (266b).

No final do diálogo, quando já se considerou o suficiente sobre a arte e a falta arte nos discursos, Sócrates propõe a Fedro considerar se é conveniente ou não conveniente escrever (274b). Narra então um relato que diz ter ouvido dos antigos e deixa a eles saber sobre sua verdade. O relato conta que uma divindade egípcia, Theuth, inventor de coisas tais como os números, a aritmética, a geometria e a astronomia, o jogo do gamão e os dados, apresentou ao Rei Thamuz os caracteres da escrita (grámmata, 274d) como um aprendizado que tornaria os egípcios mais sábios e com mais memória e, por isso, deveria ser repassado a todos eles. Ele afirma ter descoberto uma droga (phármakon, 274e) para a memória e o saber.

Contudo, o rei questiona a descoberta da divindade. Ele afirma que a escrita teria o efeito contrário, provocando o esquecimento nas almas dos que 
a aprendem, pois, por confiarem em caracteres externos, descuidariam da sua memória. Segundo Thamuz, Theuth teria descoberto uma droga (phármakon, 275a) para a rememoração (hipomnéseos) e não para a memória (mnéme). A escrita oferece aparência de saber e não verdadeiro saber.

Eis a tremenda invenção platônica, seu mito primordial, a divisão do ser em ser em si e ser derivado, em modelo e simulacro, original e cópia. Uma série de duplicações acompanha o movimento inicial no saber, na moral, na política... Em todas elas, a inferioridade do segundo termo diante do primeiro é categórica, fundadora, radical. As consequências são impressionantes: há que conhecer, proteger, admirar as primeiras tanto quanto desapreciar, controlar e combater as segundas.

Contudo, o filósofo, querendo ou não, deixa uma deixa para a escrita, por escrito. Com efeito, Platão apresenta uma brecha ainda quando sinaliza sua aparente negatividade da escrita. Por um lado, faz notar várias fraquezas, além da já apontada. Dentre elas, sua dependência: quando é ofendida, a escrita precisa da ajuda de seu pai, pois ela é incapaz de defender-se a si mesma por si mesma $(275 \mathrm{e})$. Além disso, ela se oferece indiscriminadamente aos seus leitores sem diferenciar entre os que são capazes de entendê-la e os que não. Finalmente, a escrita parece viva, mas quando é interrogada permanece em silêncio (275d), dizendo sempre uma e a mesma coisa.

Assim, curiosamente, o questionado phármakon não é pura imperfeição. Platão afirma que ele é sempre um e o mesmo, uma das notas mais destacadas das realidades supremas, em si e por si mesmas, marca de superioridade e perfeição, pois elas não mudam; a diferença das coisas que se geram e se corrompem. Deixa entrever, dessa forma, sua natureza ambivalente, incontrolável, o caráter titânico e provavelmente infrutuoso da luta por extirpá-lo do ser.

Mais ainda, o problema é de família e a dialética não terá um trabalho fácil com sua meia irmã ilegítima (276a). Efetivamente, a escrita não é apenas exterioridade. Pelo menos como metáfora, sua irmã legítima recebe dela seu nome, ela é também chamada de escrita. Vingança da escrita, contragolpe do phármakon. Platão parece ter caído em sua própria loucura: a dialética é chamada de escrita da alma: o modelo, original, toma seu nome emprestado da cópia, do simulacro (eídolon, 276a)! Não é isso, pelo menos não só: a cópia está encarnada no original, em seu nome. Como assinala Deleuze, a duplicação está seguida de um julgamento moral: as imagens dividem-se em bem fundadas e bastardas; os pretendentes, em legítimos e ilegítimos (DELEUZE, 2000, p. 262-264). Há que se diferenciar moralmente o mundo surgido da diferença. Com esse gesto, a batalha parece ganha antes de começar pelo inferior, pois desse modo confirma-se a antecedência da diferença em relação à unidade. $\mathrm{O}$ ser é diferença, mal que pesa a Platão. 
Platão sonharia, afirma Derrida, com uma memória sem suporte, sem signo, sem suplemento (DERRIDA, 1991, p. 56), absolutamente dona de suas recordações e da sua atividade de recordar. Na perspectiva platônica, a escrita, o suplemento, o apoio à memória, introduz uma fissura no ser; a de um ser híbrido, uma cópia, que não pode ser pensado segundo a lógica binária do ser ou não-ser, pois ela é e não é ao mesmo tempo. A escrita introduz uma rachadura na inteligibilidade do que é, um desdobramento desnecessário e perigoso da voz, um sintoma externo e debilitado da vitalidade da alma, uma droga (phármakon) sedutora que debilita a fortaleza e a integridade da memória e os significados que nela habitam. O lógos, como ser vivo, sofre a invasão externa de um parasita, de um meio-irmão órfão, de uma sobra, de um acréscimo que não faz outra coisa senão corroê-lo. É preciso expulsar este suplemento indesejável, devolvê-lo ao seu lugar, extirpar o parasita, o filho ilegítimo, para limpar a família. A dialética é o caminho platônico da cura. Discurso vivo e animado que se escreve na alma de quem aprende, é capaz de defender-se a si mesma e sabe falar ou calar quando necessário. Frente à dialética, a escrita é tal como uma criança órfã: sofre os efeitos do abandono quando seu pai-escritor não está próximo.

Por que Platão critica tão ferozmente a escrita por escrito? Derrida tem sua hipótese: a escrita deve servir para expurgar-se a si mesma; o lógos deve ser curado do parasita da escrita... por escrito. Esta é a ousadia e o risco de Platão, ousadia filosófica, pedagógica e epistemológica, pois não há ciência, epistéme, do phármakon, sua essência é não ter uma essência estável, mas é "o movimento, o lugar e o jogo (a produção) da diferença" (DERRIDA, 1991, p. 74). O phármakon é, por um lado, uma reserva inescrutável - "fundo sem fundo" - da diferença que "produz" todas as diferenças, o diferir da diferença.

Assim, Platão bebe do seu próprio veneno: as oposições do platonismo são derivadas de uma escrita - phármakon anterior, primeira ("arquiescrita"). A escrita é o "jogo do outro no ser" (DERRIDA, 1991, p. 118). Platão escreve porque o ser não pode ser uno, porque o ser não é presença plena e absoluta. Escreve porque o ser só pode ser se desdobrando, se repetindo no que não é, no simulacro, inscrevendo-se na estrutura da repetição suplementar de uma unidade impossível. Só há ser - e verdade - porque há diferença e repetição.

\section{A escrita e o aprender (pela Filosofia)}

A condenação platônica é uma condenação a algumas formas de exercer a escrita. Eis um dos problemas principais de Platão: existem rivais que se apresen- 
tam como mestres, educando os jovens numa certa virtude cidadã. Pressupõem que aprender a virtude é possível e a ensinam. Usam a escrita para seus próprios fins: a colocam num dispositivo de transmissão, que expressa formas do bem comum muito distantes das que Platão quer para a pólis.

Os efeitos da escrita praticada pelos rivais políticos parecem terríveis ao educador Platão: ela debilitaria a memória que é nada menos do que a fonte do aprender. Assim a apresenta no Mênon, onde conta uma história segundo a qual aprender é lembrar. Lembremos antes a primeira pergunta, essencial, do diálogo: é possível ensinar a areté (virtude; excelência)? Muitos afirmam que sim e se apresentam como capazes de fazê-lo. Contudo, Platão coloca Sócrates para pôr em questão essa pretensão. Como sempre, Sócrates coloca condições para responder essa pergunta: há que se saber o que é a areté. Mênon, experto em discursos sobre a areté, pensa que o sabe, mas depois de algumas perguntas de Sócrates não sabe mais o que dizer. Mênon está como quem sofre uma descarga elétrica e fica impossibilitado de qualquer movimento. Considera acertado que Sócrates não tenha viajado fora de Atenas, porque, sendo estrangeiro, o teriam julgado como feiticeiro.

Sócrates aceita a posição de Mênon com uma condição: "Pois não é por estar eu mesmo no bom caminho (euporôn) que deixo os outros sem saída (aporêin), senão por estar eu mesmo mais que ninguém sem saída (aporôn), assim também deixo os outros sem saída (aporêin)" (Mênon, 80c-d). As duas sentenças estão unidas por uma partícula adversativa (senão). Em ambas as frases, repete-se a parte final: produzir a aporia nos outros; o que muda é a causa colocada para esse efeito. A contraposição é entre duas eventuais posições de Sócrates, dadas respectivamente pelos prefixos eu (bem, bom) e $a$ (ausência, carência, negatividade) perante a mesma forma póros, que indica movimento, caminho, deslocamento. Sócrates afirma que aturde os outros só porque ele está mais aturdido que ninguém, porque seu saber nada vale, assim como nada valem os saberes dos outros.

É possível ensinar a virtude ou a excelência? O educador Sócrates responderia de forma paradoxal: sim e não, porque ensinar a virtude ou excelência é ensinar que não se sabe o que ela é; não há virtude ou excelência a ensinar, a não ser uma relação inquieta em relação ao saber, uma perturbação com o que se sabe, uma mania erótica por buscar saber sem nunca de fato saber nada a não ser esse não saber. Só a partir de estar problematizado um educador pode ajudar os outros a se problematizarem. Só um virtuoso pode provocar a virtude. Virtuoso é aquele que não sabe e não se ilude quanto ao seu não saber, alguém que não sabe o bom caminho, mas que está sempre à busca do bom caminho, sem jamais possuí-lo. Assim, na perspectiva socrática, só é possível aprender a virtude pelo filosofar. Só alguém muito aturdido pelo perguntar filosofante, 
que coloque em questão por que vivemos a vida que vivemos, pode provocar, nos outros, esse aturdimento. Por isso Sócrates nada escreveu, porque não tinha para ensinar nada fixo que pudesse ser escrito. Como escrever uma paixão, uma relação ao saber, um estar sempre incerto em relação ao caminho a andar, uma forma de se examinar a si mesmo como modo de viver a própria vida?

Porém, pôr em questão o que se pensa pode imobilizar o pensamento. Isso acontece com o paradoxo do aprender compartilhado por Sócrates e seus rivais. Aprender parece impossível, pois não se poderia aprender se já se sabe, mas também se não se sabe. Ninguém aprenderia o que já sabe, pois se já o sabe, não há nada a aprender; mas também não poderia aprender o que não sabe, pois como reconhecê-lo se não o sabe? Mênon quer saber como sair da aporia. Sócrates o ajuda, mas não o ajuda como um leitor da Apologia esperaria, com seu saber de não saber. Nesse caso, Platão coloca na boca de Sócrates uma teoria tomada de Píndaro e de outros religiosos, segundo a qual a alma é imortal, e investigar e aprender são totalmente uma reminiscência (Mênon, 81d). Outra vez o mistério de Sócrates e Platão, a dupla impossível.

Mênon pede a Sócrates que lhe ensine como é essa teoria. Platão se diverte e faz Sócrates responder como o Sócrates da Apologia não responderia: "Agora, tu me perguntas se eu te posso ensinar, a mim que afirmo que o ensino não é senão reminiscência" (82a). Sócrates pede a Mênon que traga um servente (um escravo não adquirido, mas criado na própria casa desde o seu nascimento) que fale grego para mostrar como de fato ele nada ensina. No transcorrer da conversa, o escravo passa de estar certo de um falso saber a uma perplexidade que o leva a querer aprender aquilo que reconheceu como problema; como resultado, aprende um conteúdo novo, matemático, um saber diferente que, na hipótese de Sócrates, ele já sabia, mas não recordava. A conclusão de Sócrates é: "Assim, pois, sem que ninguém lhe tenha ensinado, mas porque lhe perguntaram o que ele sabe, ele mesmo, por si mesmo, recobrou o saber" (Mênon, 85d).

Poderíamos questionar várias coisas: se a conclusão é legítima ou não; se de fato ninguém lhe ensinou e se o servidor aprende o que ele sabe ou o que Sócrates sabe; que outras coisas ele aprende com Sócrates, além do saber matemático. Porém, o que nos interessa aqui é mostrar que Platão faz Sócrates resolver a aporia do lado do saber com ajuda da memória: só se pode aprender o que já se sabe porque esse saber está esquecido. Só se pode ensinar o saber que o outro já sabe fazendo-o lembrar do que já sabe. Eis a saída platônica do paradoxo: aprender é reencontrar-se por intermédio de um mestre com um saber que, esquecido, já se possuía. Assim, no estado deteriorado das coisas da pólis, para Platão, aprender se torna não apenas possível, mas necessário, imprescindível para encontrar o saber perdido que ajuda o que é a se tornar o que deve ser. 
No exercício com Mênon, Sócrates não escreve, mas desenha uma figura no chão, da qual pede ao servidor uma proporção. É interessante que ele, que não escreve, precise de uma imagem sensível inscrita na terra para ajudar o outro a lembrar de seu saber. Talvez esteja sinalizando um limite, uma condição, um risco. Em qualquer caso, se é verdade que a escrita debilita a memória, então o aprender está em risco, pois sem memória não há aprendizagem. Sem aprendizagem não há possibilidade de sair do que se é e encontrar o que se deve ser, o que verdadeiramente se é, de transformar o modo em que se vive para viver uma vida justa, bela, boa. A escrita compromete a memória e com ela a aprendizagem necessária para as aspirações platônicas de formar a infância para uma pólis mais justa, bela e verdadeira.

A desqualificação da escrita no Fedro ganha novas dimensões. O embate é vital. A crítica à escrita pressupõe um campo de batalha pedagógico e político na formação dos atenienses. Curiosamente, o adversário de Platão é também seu mestre que, vimos, ocupa uma posição que contém não só a diferença, mas também a tensão, o paradoxo, a contradição. Assim, Platão embate contra não apenas os que afirmam saber o que é virtude e como ensiná-la, mas contra o próprio mestre, que afirma não saber o que é a virtude e não poder ensiná-la.

Derrida sugere algo interessante: é verdade que Platão, condenando a escrita, estaria condenando os que acusaram Sócrates por escrito. Porém, estaria também condenando a própria posição de Sócrates (DERRIDA, 1991, p. 95 ss.), seu modo de exercer uma vida filosófica em relação com a vida política, uma relação passiva e estéril na pólis, como a que ele mesmo relata na citada passagem do Teeteto e que, veremos, outros personagens também criticam nos diálogos, como Calicles no Górgias (484c) e Adimanto na República (VI $487 \mathrm{c}-\mathrm{d}$ ). A condenação à escrita teria o duplo sentido de condenar não só os acusadores, mas também seu mestre como filósofo educador, alguém que educa em nome da Filosofia, sem ensinar aprendizagens de consequências políticas desaprovadas pelo discípulo que o escreveu.

Afinal, é uma disputa sobre o valor político de aprender pela Filosofia, de uma vida filosófica. Há duas Filosofias enfrentadas: uma coloca em questão os saberes; outra é um saber afirmativo imprescindível para uma vida bela, justa e verdadeira. A Filosofia como questionamento da política instituída frente à Filosofia como afirmação do saber normativo para a pólis. A posição estrangeira e atópica do filósofo seria impotente, na visão platônica, para encontrar a positividade política que transforme o estado de coisas. Platão parece não estar disposto a aceitar essa posição e por isso a escrita (?!) dos diálogos, a fundação da Academia, as viagens à Sicília. 


\section{Os sentidos políticos do ensino de Filosofia}

Contudo, a batalha está perdida antes de ser começada. A Filosofia, como phármakon, resiste a toda captura. A pretensão política de afirmar um pensamento unitário fracassa. A diferença não é apenas primeira no ser, mas também na política e no próprio pensamento. Existe um Sócrates escondido em cada educador platônico. Como um estrangeiro, sorri perante as pretensões formativas da instituição pedagógica da Filosofia. Oferece o phármakon da pergunta, do phílos, da diferença. Não sabe o que significam aprender, ensinar, escrever. Não ensina, mas provoca aprenderes. Não escreve, mas gera escritas. Não sabe outra coisa a não ser o valor do não saber, da diferença, para uma vida que mereça a pena de ser vivida.

No Górgias, a crítica à posição socrática do filósofo/professor de Filosofia está associada a uma desvalorização da infância. Cálicles pede a Sócrates que não seja infantil e se afaste da Filosofia para se dedicar a coisas mais importantes (Górgias, 484c). Ele diz que a Filosofia corrompe os homens quando permanecem nela mais tempo que o devido, porque torna as pessoas inexperientes (apeíron) para a vida pública da pólis: os que filosofam em excesso desconhecem as leis, não sabem tratar os outros cidadãos, não são esclarecidos nem bem considerados ou experientes (émpeiron). Eles são ridículos nos assuntos públicos e privados (Górgias, 484c-d), nos quais se comportam como crianças. É isto que sucede a Sócrates. O filósofo é tão ridículo e infantil nos assuntos públicos como os políticos nas conversas filosóficas. Cálicles avança na comparação:

É belo o estudo da Filosofia até onde for auxiliar da educação, não sendo essa atividade desdouro para os jovens. Mas, perseverar nesse estudo até idade avançada, é coisa supinamente ridícula, Sócrates, reagindo eu à vista de quem assim procede como diante de quem se põe a balbuciar e brincar como criança. Quando vejo uma criança na idade de falar dessa maneira, balbuciando e brincando, alegro-me e acho encantador o espetáculo, digno de uma criatura livre e muito de acordo com aquela fase da existência; porém, se ouço uma criaturinha articular com correção as palavras, doem-me os ouvidos e acho por demais forçada essa maneira de falar, que se me afigura linguajar de escravos. (485a-b, trad. Carlos Alberto Nunes. In: PLATÃO, 2003, p. 184). 
É belo dedicar-se à Filosofia na medida em que serve para a educação (paideías), afirma Cálicles. Não há valoração de ambas: elas podem estar juntas porque ambas são, por natureza, sem importância ou, na melhor das hipóteses, uma propedêutica para o que realmente importa: a vida política dos adultos. Note-se como, na visão de Cálicles, a educação diz respeito a um mundo anterior à entrada na política. Não há política na educação; por isso a Filosofia pode estar nela junto à infância.

Na República, Adimanto argumenta numa linha bastante próxima: os que não abandonam a Filosofia depois de abraçá-la como parte de sua educação enquanto crianças (néoi) tornam-se, quando adultos, pessoas estranhas (allokótuous) ou perversas (A República, VI 487c-d). A Filosofia pode ser praticada enquanto se é novo, mas a política é o mundo dos velhos e ali ela é completamente estrangeira. Não há política na infância ou na Filosofia. Quando na mesma República a Filosofia é colocada em idade bem avançada no currículo formativo dos aspirantes a governar a pólis, é um conhecimento teórico, muito diferente da praticada por Sócrates.

O filósofo, infante, é também estrangeiro. Já o vimos no Fedro. Mostrar-se como estrangeiro é o jogo de Sócrates, afirma Derrida (1997, p. 19) e o ilustra com uma passagem da Apologia de Sócrates. É o começo. Sócrates no tribunal se declara completamente estrangeiro ao léxico do lugar (atechnôs oûn xénos écho tês entháde léxeos, 17e). E, como tal, afirma que vai falar como costuma fazê-lo na ágora, junto aos vendedores, com as mesmas palavras (dià tôn autôn lógon, 17c) com que os seus juízes ali já lhe ouviram. Solicita, então, que lhe permitam falar com a voz (phoné) e da maneira como foi criado, como se ele realmente fosse um estrangeiro. Sócrates fala como sempre, como um filósofo, com a voz e o tom de um menino. A voz do filósofo é uma voz infantil, estrangeira. De um estrangeiro, menino e filósofo, os juízes democráticos de Atenas não escutarão nada mais do que a verdade. Não há língua comum entre Sócrates e os juízes. A pólis é insensível à língua infantil e estrangeira do filósofo.

A lição poderia ser aprendida pelos que trabalhamos hoje no campo do ensino de Filosofia. Para que fazê-lo? Para que levar a Filosofia às instituições educacionais? O discurso dominante da contribuição da Filosofia à formação cidadã tem os riscos do platonismo, de falar pelo outro, de já saber o justo, o belo, o bom por vir. Ao contrário, a figura paradoxal de Sócrates afirma a força política da alteridade, da diferença. Justamente, a força política de sua Filosofia (em Sócrates não há como separar o filósofo do professor de Filosofia) está no seu caráter infantil: ela não sabe, não ensina, não forma. Estrangeira e estranha aos modos de afirmar a palavra na comunidade, ela mostra o valor de buscar saber sobre si antes que sobre as outras coisas, de problematizar e desaprender o que se sabe e afirmar o valor do não saber, de tentar responder, com todas as 
forças, aquelas perguntas que não podem ser respondidas. Essa Filosofia não é um saber, mas uma relação ao saber. Ela é inútil para construir um projeto político-pedagógico. Ela ajuda a questionar os projetos político-pedagógicos existentes. Eis sua força filosófica, pedagógica e política. Por isso, na visão de Platão, não é apenas inútil: é também perigosa. Por isso deve ser expurgada da pólis, porque não pode dar lugar a nenhum currículo, a nenhum edifício pedagógico que possa fazer da pólis um lugar mais belo, bom e justo. Mas a diferença resiste na escrita condenada e o Sócrates dos diálogos deixa ver outros mundos na Filosofia, na educação e na política. Quem sabe o presente texto tenha ajudado o leitor a problematizar o sentido de seu fazer. Terá assim recriado a vida e o enigma infinito da Filosofia: para que ensiná-la? Para que Filosofia? Para quê?

\section{REFERÊNCIAS}

DELEUZE, Gilles. Platon te le simulacre. In: . Logic du sens. Paris: Les Éditions de Minuit, 1995. Trad. Port.: Lógica do sentido. Trad. Luiz Roberto Salinas Fortes. São Paulo: Perspectiva, 2000.

DERRIDA, Jacques. La pharmacie de Platon. En: PLATON. Phèdre. Traduction L. Brisson. Paris: GF-Flammarion, 1968/2000, p. 255-403. Trad. port.: A Farmácia de Platão. Trad. Rogério Costa. São Paulo: Iluminuras, 1991. . La carte postale. Paris: Flammarion, 1980.

. De l'hospitalité. Anne Dufourmantelle invite Jacques Derrida à répondre. Paris: Calmann-Lévy, 1997.

KOHAN, Walter Omar. Sócrates \& a educação. O enigma da Filosofia. Belo Horizonte: Autêntica, 2011.

LIDDELL, Henry; SCOTT, Robert. A Greek English Lexicon. Oxford: Clarendon Press, 1966.

PLATÃO. Diálogos. Trad. Carlos Alberto Nunes. Belém: UFPA, 2003.

Texto recebido em 03 de fevereiro de 2012.

Texto aprovado em 10 de junho de 2012. 